preponderance of cases in the southern part of this region, would seem to indicate that the relatively cooler and dryer climate of Northern Nigeria is a less favourable environment for the lymphoma syndrome. However, the apparent incidence of disease in an underdoctored area often depends on the incidence of doctors and on their medical interests. A further analysis of the total biopsy figures in this region during 1963-4 reveals

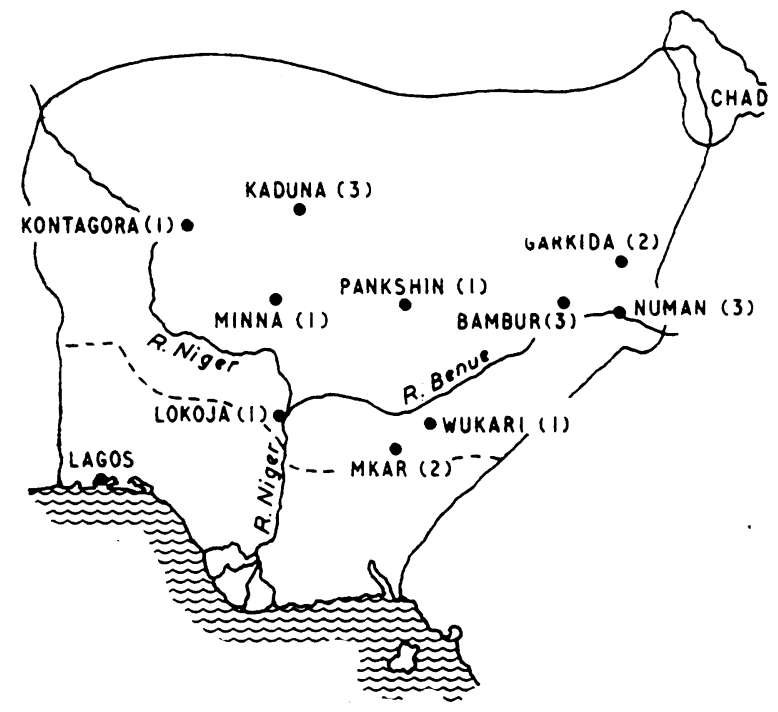

FIG. 3.-Towns from which cases of Burkitt's tumour came.

The number of cases from each town is shown in parentheses.

that 923 specimens were received from hospitals south of the Garkida-Kaduna-Kontagora line, and only 247 were from north of this line. Moreover, of the 126 children on whom biopsy was made, only 23 came from hospitals north of Kaduna.

During the same year 367 biopsies were examined at the Kano Pathology Laboratory. Twenty were from patients of
15 years and under, and 10 of these demonstrated malignant tumours. One, a tumour of jaw in a boy of $3 \frac{1}{2}$ years, was said to be a lymphosarcoma. It seems reasonable to suppose that this could be another case of Burkitt's tumour (F. Vivarelli, personal communication, 1964).

The six other malignant lymphomata of children seen at Kaduna during the year consisted of three lymphosarcomas, two reticulum-cell sarcomas, and one Hodgkin's disease, all involving lymph nodes.

\section{Summary}

The lymphoma syndrome undoubtedly occurs in the Northern Region of Nigeria. Eighteen cases were seen at the Kaduna Regional Pathology Laboratory during the year 1963-4, this representing about $50 \%$ of all malignant tumours of childhood. All the cases came from the southern part of the Northern Region, although one possible additional case was seen at Kano Pathology Laboratory, which receives specimens from the near-by hospitals in the northern part of this region.

I wish to thank the clinicians in the Northern Region of Nigeria for referring specimens to me for examination, and also the Principal Medical Officer in the Northern Nigerian Ministry of Health for permission to publish these cases.

\section{REFERENCES}

Burkitt, D. (1958). Brit. F. Surg., 46, 218. (1962a). Nature (Lond.), 194, 232. (1962b). Ann. roy. Coll. Surg. Engl., 30, 211 (1962c). Brit. med. F., 2, 1019. and O'Conor, G. T. (1961). Cancer, 14, 258

Edington, G. M. (1956). Brit. F. Cancer, 10, 595.

and Maclean, C. M. U. (1964). Brit. med. 7., 1, 264

Elmes, B. G. T., and Baldwin, R. B. T. (1947). Ann. trop. Med. Parasit., 41, 321 .

Smith, E. C., and Elmes, B. G. T. (1934). Ibid., 28, 461.

Wright, D. H. (1963). Brit. F. Cancer, 17, 50.

\title{
Lincomycin Hydrochloride: Clinical and Laboratory Studies
}

\author{
A. M. GEDDES,* M.B., M.R.C.P.ED. ; R. A. SLEET, $\dagger$ M.B., CH.B. ; J. MCC. MURDOCH, $\ddagger$ F.R.C.P.ED., M.R.C.P.GLASG.
}

Lincomycin was isolated from Streptomyces lincolnensis in 1955 and later described by Mason et al. (1962). The hydrochloride is a white crystalline solid with an empirical formula of $\mathrm{C}_{18} \mathrm{H}_{34} \mathrm{~N}_{2} \mathrm{O}_{6}$ S. $\mathrm{HCl} . \frac{1}{2} \mathrm{H}_{2} \mathrm{O}$ and when stored at $70^{\circ} \mathrm{C}$. for six months shows no detectable degradation. It is very soluble in water and soluble in methanol and ethanol (Herr and Bergy, 1962). In vitro the antibiotic has comparable activity against the same range of Gram-positive organisms as erythromycin (Lewis et al., 1962).

Bacterial resistance to lincomycin develops slowly in vitro (Lewis et al., 1962) and lack of cross-resistance with other antibiotics has been reported from the United States (Mason et al., 1962 ; Walters et al., 1963 ; Clapper et al., 1964). Recent work in the United Kingdom, however, indicates the possibility of dissociated cross-resistance with the macrolides (Barber and Waterworth, 1964).

\footnotetext{
* Senior Registrar, Infectious Diseases Unit, City Hospital, Edinburgh. + Former Registrar, Infectious Diseases Unit, City Hospital, Edinburgh. ‡ Consultant Physician, Infectious Diseases Unit, City Hospital, Edin-
} burgh.
The absorption and excretion characteristics of lincomycin have already been reported (Ma et al., 1963 ; Medina et al., 1963 ; Vavra et al., 1963). It is acid-stable, and animal experiments have shown that most of an ingested dose had left the stomach within two hours in the fasting state. Food in the stomach, however, delayed absorption by more than an hour (Meyer and Lewis, 1963). Oral doses are well absorbed from the upper small bowel, giving peak serum levels after four hours. Higher and more rapidly attainable peak levels can be achieved by intramuscular injection. Twenty-four-hour excretion studies show a variable recovery from the urine, averaging $13 \%$ of an oral dose, and $33 \%$ recovery from the faeces. The fate of the remainder is unknown. Tissue-level estimations indicate that significant concentrations are present in most body tissues, but not in the cerebrospinal fluid, and that bile may be an important route of excretion.

Particular attention has been drawn to the amounts of lincomycin (1.1-6.6 $\mu \mathrm{g}$. $/ \mathrm{g}$.) found in specimens of bone (Holloway et al., 1963), suggesting that this antibiotic may prove valuable in the treatment of staphylococcal osteomyelitis. 
In view of these characteristics, and since no serious toxicity has been reported during the clinical investigation of lincomycin in both this country and the United States (a total of approximately 2,500 patients), it was decided to treat with this antibiotic selected patients who were suffering from various acute and chronic Gram-positive infections, with special emphasis on chronic and refractory osteomyelitis. The results of such treatment in 24 patients aged 12 to 77 years are reported.

\section{Materials and Methods}

When possible, the infecting organism was isolated prior to starting treatment. Antibiotic sensitivities were determined by the disk-diffusion method for the standard drugs, and for lincomycin the minimum inhibitory concentration (M.I.C.) was determined by the tube-dilution method. A penicillin-resistant Staphlococcus aureus was obtained from 15 patients, Streptococcus haemolyticus from four, but no organism was obtained from five. Of the latter, four had " closed" osteomyelitis with sterile blood cultures, and the fifth had a cellulitis without sinus formation.

Lincomycin hydrochloride was given orally in capsules in doses of 250 or $500 \mathrm{mg}$. six-hourly. Serum levels were estimated at random periods between two and six hours after a dose of the drug given to all patients before food, using Sarcina lutea as the test organism (Hanka et al., 1962). During treatment, full blood counts, urinalysis, and S.G.P.T. serum levels were estimated. Details of treatment, which varied in duration from five days to nine months, are shown in Table I. Four illustrative cases are described more fully as follows.

Case 6.-A 77-year-old man fractured his left femur 40 years ago. In 1963 he presented with a discharging sinus of his left hip from which repeated cultures were sterile. There was radiological evidence of widespread femoral destruction. A therapeutic trial of antituberculosis chemotherapy was unsuccessful, and the only possible surgical procedure-hindquarter amputation-was contraindicated because of his age. Treatment was started with lincomycin with slow but very definite improvement. The sinus closed and the E.S.R. fell from 73 to $20 \mathrm{~mm}$. in the first hour. He was able to walk and and has been discharged to a convalescent hospital. To date he has received lincomycin for 120 days without clinical or biochemical evidence of toxicity.

Case 16.-A 13-year-old girl required aortic valvulotomy in March 1963. She developed post-operative staphylococcal septicaemia, which responded to cloxacillin therapy. Six months later she was readmitted to hospital with fever and Staph. aureus was again isolated from blood cultures. She was re-treated with cloxacillin, but after two days there was no clinical response and treatment was changed to lincomycin. Her condition then gradually improved and she was completely afebrile after six days. Lincomycin treatment was continued after her discharge from hospital. Eleven months after the initial operation she had a second successful operation for the repair of a false aneurysm of the aorta. Swabs taken from the endocardium and the aneurysm were sterile. Linomycin was finally discontinued after a total of nine months' treatment.

Case 8.-A 49-year-old man developed a chronic discharging sinus after an arthrodesis of the hip in 1956. Seven years later he was readmitted to hospital with a large abscess in his thigh associated with septicaemia, the causative organism being a penicillin-resistant Staph. aureus. After the abscess was drained treatment with lincomycin was begun and the temperature rapidly fell to normal. Within 14 days the discharge from the wound was minimal and healing well advanced.

Case 7.-A 14-year-old boy was admitted to hospital with clinical and radiological evidence of acute osteomyelitis of a left tibial condyle. Lincomycin treatment produced a clinical response, with a fall in the E.S.R. from 70 to $18 \mathrm{~mm}$. in the first hour. After two months' treatment $x$-ray films of the left tibia were normal.

\section{Results}

Nineteen of the 24 patients receiving lincomycin showed complete clinical recovery. Bacteriological cure was achieved in 14 patients with positive pretreatment cultures. Five patients failed to respond to treatment. In two this was due to superinfection with Gram-negative organisms ; underlying carcinoma was demonstrated in one, and in another there was inadequate drainage of an empyema. One patient failed to respond for no apparent reason. There were no deaths.

The M.I.C. of the causative organisms for lincomycin was usually 0.5 or $1 \mu \mathrm{g} . / \mathrm{ml}$. In two patients, however, it was 4 $\mu \mathrm{g} . / \mathrm{ml}$. Table II shows the results of 160 serum lincomycin assays. It will be seen that $80 \%$ of the levels were between 0.5 and $16 \mu \mathrm{g} . / \mathrm{ml}$. During the early weeks of the trial levels greater than $32 \mu \mathrm{g} . / \mathrm{ml}$. were reported, but these were never found when the technique for the assay was perfected. It is felt that these results were erroneous, possibly because of contamination of the test organism or the containers by antibacterial substances. In one patient who failed to respond the serum lincomycin levels did not exceed or equal the M.I.C. for the causative organism. Otherwise serum levels were always in excess of the pretreatment M.I.C. for the organism.

TABLE I.-Details of Lincomycin Treatment

\begin{tabular}{|c|c|c|c|c|c|c|}
\hline $\begin{array}{l}\text { Case } \\
\text { No. }\end{array}$ & $\begin{array}{c}\text { Age } \\
\text { (Yrs.) }\end{array}$ & Diagnosis & $\begin{array}{l}\text { Organism } \\
\text { and } \\
\text { M.I.C. } \\
(\mu \mathrm{g} . / \mathrm{ml} .)\end{array}$ & $\begin{array}{l}\text { Daily Dose } \\
\text { of } \\
\text { Lincomycin }\end{array}$ & $\begin{array}{c}\text { Duration } \\
\text { of } \\
\text { Treatment } \\
\text { (Weeks) }\end{array}$ & Result \\
\hline 1 & 36 & $\begin{array}{l}\text { Osteomyelitis } \\
\text { tibia }\end{array}$ & S. $\underset{0.5}{\text { aureus }}$ & $2 \mathrm{~g}$. & 4 & Success \\
\hline 2 & 12 & $\begin{array}{l}\text { Osteomyelitis } \\
\text { ischium }\end{array}$ & Nil & $1 \mathrm{~g}$ & 4 & ," \\
\hline 3 & 46 & $\begin{array}{l}\text { Osteomyelitis } \\
\text { lumbar spine }\end{array}$ & Nil & $2 \mathrm{~g}$. & 8 & " \\
\hline 4 & 55 & $\begin{array}{l}\text { Osteomyelitis } \\
\text { femur }\end{array}$ & S. aureus & $2 \mathrm{~g}$. & 1 & Failure \\
\hline 5 & 19 & $\begin{array}{l}\text { Osteomyelitis } \\
\text { tibia }\end{array}$ & S. aureus & $2 \mathrm{~g}$. & 1 & و, \\
\hline 6 & 77 & $\begin{array}{l}\text { Osteomyelitis } \\
\text { femur }\end{array}$ & Nil & $2 \mathrm{~g}$. & 17 & Success \\
\hline 7 & 14 & $\begin{array}{l}\text { Osteomyelitis } \\
\text { femur }\end{array}$ & Nil & $2 \mathrm{~g}$. & 8 & " \\
\hline 8 & 49 & $\begin{array}{l}\text { Septic arthritis } \\
\text { hip }\end{array}$ & S. aureus & $2 \mathrm{~g}$. & 8 & " \\
\hline 9 & 12 & $\begin{array}{l}\text { Broncho- } \\
\text { pneumonia }\end{array}$ & S. aureus & $2 \mathrm{~g}$. & 2 & " \\
\hline 10 & 12 & $\begin{array}{l}\text { Septic arthritis } \\
\text { elbow }\end{array}$ & S. aureus & $1.5 \mathrm{~g}$ & 4 & ", \\
\hline 11 & 24 & Paronychia & S. aureus & $1 \mathrm{~g}$. & 1 & Failure \\
\hline 12 & 70 & $\begin{array}{l}\text { Infected ulcer of } \\
\text { foot }\end{array}$ & S. aureus & $2 \mathrm{~g}$. & 4 & Success \\
\hline $\begin{array}{l}13 \\
14\end{array}$ & $\begin{array}{l}32 \\
74\end{array}$ & $\begin{array}{l}\text { Cellulitis of leg } \\
\text { Wound infection }\end{array}$ & S. $\underset{1}{\text { aureus }}$ & $\begin{array}{l}2 \mathrm{~g} . \\
2 \mathrm{~g} .\end{array}$ & $\begin{array}{l}1 \\
2\end{array}$ & ", \\
\hline 15 & 67 & $\begin{array}{l}\text { Urinary infection } \\
\text { and epididymo- } \\
\text { orchitis }\end{array}$ & S. aureus & $2 \mathrm{~g}$. & 2 & Failure \\
\hline $\begin{array}{l}16 \\
17 \\
18 \\
19\end{array}$ & $\begin{array}{l}13 \\
21 \\
68 \\
53\end{array}$ & $\begin{array}{l}\text { Septicaemia } \\
\text { Septic arthritis } \\
\text { Enteritis } \\
\text { Chronic empyema }\end{array}$ & $\begin{array}{l}S . \text { aureus } \\
S . \text { aureus } \\
S . \text { aureus } \\
S . \text { aureus } \\
0.5\end{array}$ & $\begin{array}{l}2 \mathrm{~g} . \\
2 \mathrm{~g} . \\
2 \mathrm{~g} . \\
2 \mathrm{~g} .\end{array}$ & $\begin{array}{r}36 \\
8 \\
2 \\
6\end{array}$ & $\begin{array}{c}\text { Success } \\
\text { ", } \\
\text { Failure }\end{array}$ \\
\hline 20 & 62 & Enteritis $\quad$. & S. aureus & $2 \mathrm{~g}$. & 3 & Success \\
\hline $\begin{array}{l}21 \\
22 \\
24 \\
24\end{array}$ & $\begin{array}{l}52 \\
60 \\
64 \\
52\end{array}$ & $\begin{array}{l}\text { Erysipelas } \\
\text { Erysipelas } \\
\text { Erysipelas } \\
\text { Cellulitis of face } \\
\quad \text { and neck }\end{array}$ & $\begin{array}{l}\text { H. strep. } \\
H . \text { strep. } \\
H . \text { strep. } \\
\text { H. strep. }\end{array}$ & $\begin{array}{l}1 \mathrm{~g} . \\
1 \mathrm{~g} . \\
1 \mathrm{~g} . \\
2 \mathrm{~g} .\end{array}$ & $\begin{array}{l}1 \\
1 \\
1 \\
4\end{array}$ & $\begin{array}{l}\text { "' } \\
\text { ", }\end{array}$ \\
\hline
\end{tabular}

TABLE II.-Results of 160 Serum Lincomycin Assays

\begin{tabular}{|c|c|c|c|c|c|c|c|}
\hline $\begin{array}{l}\text { Lincomycin }(\mu \mathrm{g} . / \mathrm{ml} .) \\
\text { No. of estimations } . .\end{array}$ & 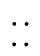 & $\begin{array}{l}<2 \\
18\end{array}$ & $\begin{array}{r}2 \\
24\end{array}$ & $\begin{array}{r}4 \\
32\end{array}$ & $\begin{array}{r}8 \\
32\end{array}$ & $\begin{array}{l}16 \\
27\end{array}$ & $\begin{array}{l}32 \\
15\end{array}$ \\
\hline
\end{tabular}

Of 184 strains of Staph. aureus isolated in the Western General Hospital, Edinburgh, during a three-month period $70 \%$ were found to be penicillin-resistant but sensitive to methicillin, erythromycin, and lincomycin. Of the 184 strains, 46 were erythromycin-resistant, 10 methicillin-resistant, and 2 lincomycin-resistant.

Side-effects.-Mild diarrhoea, transient in character, occurred in two patients. One (Case 6) received $2 \mathrm{~g}$. of lincomycin daily for 120 days, while another (Case 16) received the drug for nine months. Neither of these patients showed any evidence of toxicity either clinically or in blood findings or S.G.P.T. serum levels.

\section{Discussion}

Lincomycin hydrochloride has certain advantages in hospital practice. It is acid-stable and can be given orally for long 
periods of time without the risk of serious toxicity. The drug therefore is useful where a patient is infected by a penicillinresistant staphylococcus and cannot be given one of the new penicillins because of drug-sensitization, or where resistance to one or other of the new penicillins has been demonstrated. Because there is now in certain hospital areas an additional risk of infection with erythromycin-resistant staphylococci the drug should also be considered in these circumstances. It may be that there is a theoretical risk of the ultimate emergence of cross-resistance between the macrolides and lincomycin as suggested by Barber and Waterworth (1964). At present, however, this does not appear to have clinical significance, and since lincomycin is not related chemically to the macrolides the possible danger may be minimal. From a clinical point of view the drug appears to be particularly valuable in the treatment of staphylococcal osteomyelitis and there is some theoretical and clinical evidence to support this (Holloway et al., 1963 ; McDougall et al., 1964). Further studies are at present being initiated to assess the value of lincomycin in experimental osteomyelitis in animals.

\section{Summary}

Twenty-four patients with various infections caused by Gram-positive organisms were treated with a new antibiotic, lincomycin hydrochloride. Treatment succeeded in 19 patients and there were no untoward side-effects or toxicity in the series.

We wish to thank Dr. R. G. Jacomb, of Upjohn Limited, England, for generous supplies of lincomycin hydrochloride. We also thank Miss Edith Wallace for technical assistance, and Dr. J. C. Gould, of the Western General Hospital, Edinburgh, for the in vitro studies of staphylococci in his laboratory.

\section{REFERENCES}

Barber, M., and Waterworth, P. M. (1964). Brit. med. F., 2, 603.

Clapper, W. E., Meade, G. H., and Stewart, D. B. (1964). Amer. F. med. Sci., 247, 274.

Hanka, L. J., Mason, D. J., Burch, M. R., and Treick, R. W. (1962). Antimicrobial Agents and Chemotherapy, p. 565.

Herr, R. R., and Bergy, M. E. (1962). Ibid., p. 560.

Herr, R. R., and Bergy, M. E. (1962). Ibid., p. 560.

Holloway, W. J., Kahlbaugh, R. A., and Scott, E. G. (1963). Ibid.,

Ma, P., Lim, M., and Nodine, J. H. (1963). Antimicrobial Agents and Chemotherapy, p. 183.

McDougall, A., McMillan, N. L., and McRae, R. K. (1964). In press

Mason, D. J., Dietz, A., and Deboer, C. (1962). Antimicrobial Agents and Chemotherapy, p. 554.

Medina, A., Fiske, N., H jelt-Harvey, I., Brown, C. D., and Prigot, A. (1963). Ibid., p. 189.

Meyer, C. E., and Lewis, C. (1963). Ibid., p. 169.

Meyer, C. E., and Lewis, C. (1963). Ibid., p. 169.
Vavra, J. J., Sokolski, W. T., and Lawson, J. B. (1963). Ibid., p. 176.

Vavra, J. J., Sokolski, W. T., and Lawson, J. B. (1963). Ibid., p. 176.
Walters, E. W., Romansky, M. J., and Johnson, A. C. (1963). Ibid., p. 210 .

\title{
Haemodialysis Disequilibrium
}

\author{
S. M. ROSEN,* M.B., M.R.C.P., M.R.C.P.ED. ; K. O’CONNOR,† B.SC. ; STANLEY SHALDON, $\ddagger$ M.A., M.D., M.R.C.P.
}

Brit. med. 7., 1964, 2, 672-675

Several observers have noted a deterioration in the clinical condition of some patients during haemodialysis at a time when there is improvement in the blood biochemistry (Merrill, 1961 ; Kennedy, Linton, and Eaton, 1962 ; Sitprija and Holmes, 1962). The first evidence of this deterioration is increasing lassitude, headache, drowsiness, and confusion. In more severe cases there is an increase in blood-pressure, pulse rate, and respiratory rate. Fatalities may occur after cardiac arrest or pulmonary oedema. The syndrome is more severe when the plasma urea is very high before dialysis, and may last for 24 hours after the termination of dialysis.

Kennedy et al. (1962) noted that urea is removed more slowly from lumbar cerebrospinal fluid (C.S.F.) than from blood and suggested that the abnormal urea gradient thus established between C.S.F. and blood is responsible for this deterioration.

Investigations have therefore been performed to determine the relation between the concentration of plasma urea before dialysis and the size of the abnormal urea gradient established during dialysis, the duration of this abnormal urea gradient, and whether a similar phenomenon occurred with uric acid, creatinine, inorganic phosphorus, and bicarbonate. Observations were also made to correlate these changes in biochemical equilibrium with changes in the C.S.F.-plasma osmolality gradient.

\section{Methods}

Ten patients with acute renal failure were dialysed for periods of four to eight hours on a twin-coil kidney at bloodflow rates of approximately $200 \mathrm{ml} . / \mathrm{min}$. The rinsing fluid contained a concentration of $2 \%$ dextrose and $30 \mathrm{mEq} / 1$. of bicarbonate ion. Simultaneous samples of lumbar C.S.F. and arterial blood were obtained anaerobically immediately before dialysis, immediately after dialysis, and 16 and 24 hours after dialysis. Analysis of lumbar C.S.F. and plasma was performed for concentration of urea by the urease method with nesslerization (Varley, 1962), uric acid (Henry, Sobel, and Kim, 1957), creatinine (Owen, Iggo, Scandrett, and Stewart, 1954), and inorganic phosphorus (Fiske and Subbarow, 1925). Osmolality of C.S.F. and plasma was determined from the depression of freezing-point, using the Fiske osmometer. $p \mathrm{H}$ and $\mathrm{PCO}_{2}$ were estimated in blood and C.S.F. by means of the micro Astrup apparatus, and the concentration of bicarbonate ion was calculated using the equation $\mathrm{HCO}_{3}=\operatorname{antilog}\left(p \mathrm{H}-p \mathrm{~K}^{1}\right)\left(\mathrm{PCO}_{2} \times\right.$ $S$ ). A value for $S$ of 0.0304 was taken for plasma (Severinghaus, Stupfel, and Bradley, 1956) and a value of 0.0320 for spinal fluid (Shohl and Karelitz, 1926). $p \mathrm{~K}^{1}$ was calculated from the equations $p \mathrm{~K}^{1}$ plasma $=-0.062 p \mathrm{H}$ plasma +6.56 and $p \mathrm{~K}^{1}=-0.143 p \mathrm{H}$ C.S.F. +7.15 (Cowie, Lambie, and Robson, 1962).

One sample of arterial blood and lumbar C.S.F. was also obtained anaerobically from fasting control subjects without renal dysfunction, and analysed by the above techniques.

\section{Results}

The relation of the urea gradient (C.S.F. minus plasma) to the concentration of plasma urea before dialysis is shown in

* Medical Registrar, Renal Unit, Department of Medicine, Royal Free Hospital, London. Present address: Department of Medicine, the General Infirmary at Leeds.

+ Biochemist, Renal Unit, Department of Medicine, Royal Free Hospital, London.

‡ Lecturer in Medicine, Renal Unit, Department of Medicine, Royal Free Hospital, London. 